\section{Terror og horror hos de klassiske gotiske forfattere: Ann Radcliffe og Matthew \\ Lewis}

\section{Af bibliotekar Nina Kopp}

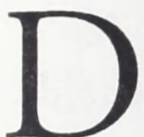

en gotiske roman i England havde en historisk baggrund for sin opståen. Den var hverken et pludseligt modefænomen eller en spontan revolution, men var snarere et udslag af en naturlige udvikling. Den gotiske genre opstod som en reaktion mod oplysningstiden, hvis litteratur søgte at beskrive menneskets hverdag på en realistisk og nøgtern måde. Men den gotiske roman vendte sig fra den formelle og stive rationalisme mod en mørkere og mere subjektiv fortolkning af livet. Man ønskede at fjerne fornuften og hengive sig til noget større og uforklarligt.

Den gotiske roman var en del af den "Renaissance of Wonder", som karakteriserede de sidste fire årtier af det 18. århundrede. Den påvirkede havekunsten og arkitekturen, men fremfor alt litteraturen. Den gotiske genre var en del af den præromantiske bevægelse, som førte Europa ind i en tid, sitrende af nye ideer, tanker og mål. Tiden var præget af længsel, anelse og mystik, og fra disse elementer udgik den gotiske genre. Den søgte tilbage i tiden og så i den fjerne middelalder en atmosfære, hvor fantasien dominerede. The Castle of Otranto (1764) af Horace Walpole er den første roman i moderne forstand, der henlægger handlingen til et middelalderligt mil- jø og inspirerer senere forfattere som Ann Radcliffe og Walter Scott. Den feudale tyran og slottet med dets massive vægge og hængebro, dybe hvælvinger og hemmelige gange er alle inspireret af middelalderen, og er elementer, som den gotiske roman i sin videre udvikling tager op og perfektionerer.

Det gotiske slot er blevet synonym med genren. Inden for sine mure omslutter slottet hovedpersonerne med hemmeligheder, løgne og kriser, og bestemmer i sidste ende deres undergang eller frelse. Slottet er et symbol på liv og død, på lidenskab og frygt, ondskab og overnaturlige kræfter. Den gotiske roman skaber med slottet som baggrund et univers præget af håbløshed og frygt. Her hersker de ukontrollerede kræfter, enten naturlige eller overnaturlige, ingen er fuldstændig sikker, intet er trygt.

Mennesket forsøger fortvivlet at opretholde kontrollen, men ser sig konstant besejret og må give sig i sine følelsers vold. Intet er mere skrækindjagende end muligheden for, at dxmoner overtager kontrollen med verden, og at det onde vil sejre over det gode. Selv om det onde ikke nødvendigvis behøver at sejre, som det er tilfældet i Matthew Lewis' roman The Monk er den forfærdende udsigt til, at det måske vil ske, et væsentligt moment $\mathrm{i}$ den gotiske roman.

Genrens store succes skyldtes en erkendelse af, at mennesket higer efter spænding og mystik og at dens forfattere skabte en litteratur, der var skræddersyet til publikum. Læserens engagement $i$ dette gotiske univers er fundamentet $i$ hele genren. At oplevelsen af et sådant kaotisk univers kunne være en 
sublim oplevelse fik sit teoretiske grundlag i Edmund Burkes Philosophical Enquiry into the Origins of our Ideas of the Sublime and Beautiful, der udkom i 1757. Her fremlægger Burke sin teori om, at det smukke, det ophøjede, kun kan dannes via smerte. Det rationelle skal fjernes for at man kan få det størst udbytte af det sublime, som ligger i det frygtindgydende, det rædselvækkende, det kaotiske og smertelige:

"Astonishment is that state of the soul in which all its motions are suspended with some degree of horror. In this case the mind is so entirely filled with its object that it cannot entertain any other, nor by consequence reason on that object which employs it. Hence arises the great power of the sublime, that, far from being produced by them, it anticipates our reasonings and hurries us on by an irresistible force ... Indeed, terror is in all cases whatsoever, either more openly or latently, the ruling principle of the sublime".'

Burke skabte rammerne for den gotiske roman ved at fastslå, at menneskets frygt kun kunne vækkes ved at dets sind blev "hurried out of itself by a crowd of great and confused images, which affect because they are crowded and confused." Denne forvirring af læserens sanser kædet sammen med frygten for det ukendte er drivkraften i den gotiske roman.
Terror og horror

$\mathrm{M}$ ed udgivelsen af Horace Walpoles roman var prototypen på den gotiske roman skabt. Men den gotiske romans videre udvikling viser, at genren hurtigt delte sig $\mathrm{i}$ to vidt forskellige bevægelser. Clara Reeve og hendes roman The Old English Baron: A Gothic Story, 1780 (opr. udgivet i 1777 under den ikke særlig gotiske titel The Champion of Virtue), ønskede at beholde Walpoles middelalderstemning, men ville undgå de fantastiske og overdrevne hændelser og holde det overnaturlige på et lidt mere acceptabelt niveau. Andre forfattere som William Beckford i sin Vathek: An Arabian Tale, from an Unpublished Manuscript fra 1786 nægtede at indgå et sådan kompromis og søgte ud over grænserne sat af Walpole, og pressede genren til det yderste med sensationelle, eksotiske og overnaturlige hændelser. Disse to grupper inden for den gotiske roman udviklede sig og modnedes igennem 1770 'erne og 1780 'erne. I 1790'erne nåede den gotiske roman sit højdepunkt med de to store forfattere: Ann Radcliffe og Matthew Lewis. De to kom hurtigt til at repræsentere to vidt forskellige skoler.

Ann Radcliffe var en del af "The School of Terror" også kaldet den naturlige gotik. Denne skole er kendetegnet ved teknikken "explained supernatural", hvor historien bygges op omkring en række mystiske og overnaturlige hændelser. Læserens fantasi pirres ved fremkomsten af spøgelser, ved brug af fantom-effekter og halvt hørte lyde, som holder læseren i spændt forventning over flere hundrede sider for til sidst at for- 


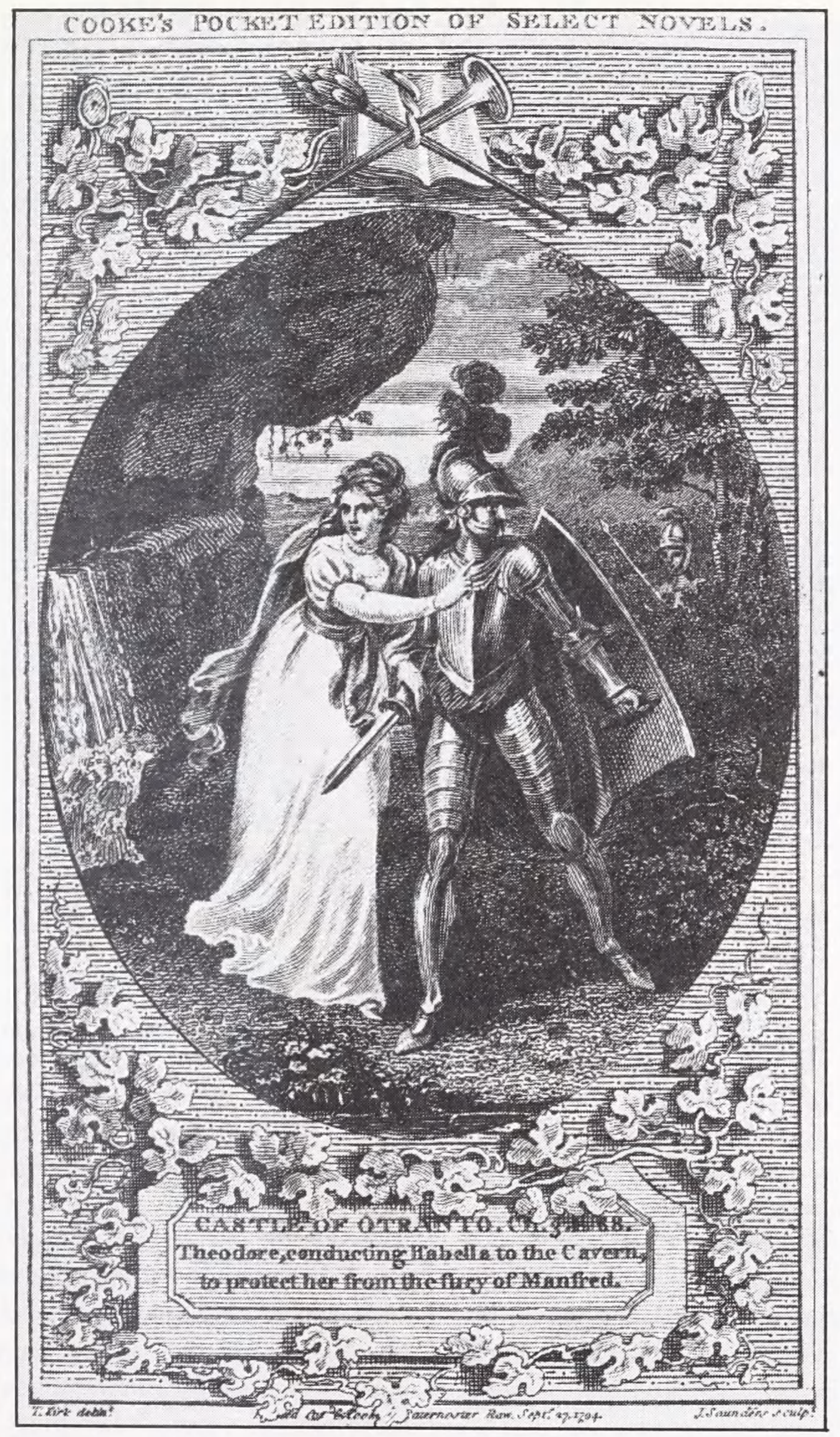

- Frontispice til 1795-udgaven af The Castle of Otranto. Forsteudgaven fra 1764 blev udgivet anonymt, mens denne bar forfatterens navn, Horace Walpole. 
klare dem som rationelle fænomener.

Matthew Lewis repræsenterede den anden skole "The School of Horror" eller den overnaturlige gotik, som har nære forbindelser til den tyske Schauerromantik. Den gotiske horrorroman er langt mere realistisk og grusom i sin udtryksform. Her skal de overnaturlige hændelser tages for ægte. Den afgørende forskel mellem disse to skoler er deres måde at skabe frygt og rædsel på. Ann Radcliffe var den første til at skelne mellem disse to begreber $i$ et essay med titlen "On the Supernatural in Poetry" udgivet posthumt i The New Monthly Magazine i 1826: "Terror and horror are so far opposite, that the first expands the soul, and awakens the faculties to a high degree of life; the other contracts freezes and nearly annihilates them. And where lies the great difference between horror and terror, but in uncertainty and obscurity, that accompany, the first, respecting the dreader evil?"2 Terror formår at vække det sublime, som horror $\mathrm{i}$ sin ligefremhed og voldsomhed mangler. Personerne i de gotiske romaner er 'terrified' ved tanken om, hvad der vil ske, hvis lyset pludselig går ud, men de er 'horrified' når lyset går ud, og det, de har frygtet for, f.eks. et spøgelse pludselig dukker op. Forskellen mellem terror og horror er således mere et spørgsmål om intensiteten af det frygtindgydende end af arten. Terror er karakteriseret ved en frygtelig spænding, mens horror skabes ved chokket over, at det overnaturlige realiseres $i$ al sin gru.

\section{т н}

MYSTERIES OF UDOLPHO, $\mathbf{A}$

$R O M A N C E$;

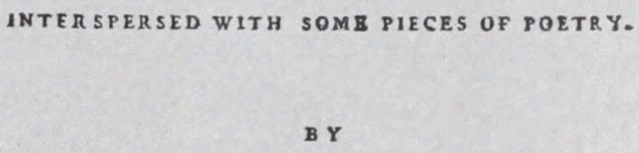

A NN RADCLIFFE, AUTHOR OF THE ROMANCE OF THE FORBST, RTC. IN FOUR VOLUMES.

Fate fits on thefc dark battlements, and frowns, And, as the portals open to receive me,

Her voice, in fullen echoes through the courts, Tells of a namelefs deed.

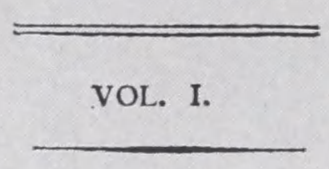

LONDON:

PRINTED SOR G. G. AND J. ROBINSON, PATERNOSTER-ROW.

I 794.

Titelblad fra Ann Radcliffe's The Mysteries of Udolpho, 1794.

\section{Ann Radcliffe og "The Mysteries of Udolpho"}

nn Radcliffe, "the great enchantA ress of that generation", som De Quincy kaldte hende, skrev sit mesterværk The Mysteries of Udolpho i 1794. En roman, hvis gotiske ideer og teknikker fik en vidtgående betydning, som ikke kan undervurderes. Romanen var en øjeblikkelig succes, og Radcliffe fik udbetalt den efter datidens forhold uhyre sum af $£ 500$ i honorar. Radcliffe havde ramt plet med sin kombination af rædselsvækkende begivenheder, en smuk heltinde og beskrivelsen af de maleriske 
omgivelser. Romanen afstedkom en flodbølge af "chapbooks", hvor mindre talentfulde forfattere forsøgte at gå i hendes fodspor, mens Jane Austen i Northanger Abbey (skrevet i 1797, men først udgivet posthumt i 1818) lavede en afdæmpet parodi over Udolpho.

\section{The Mysteries of Udolpho kan}

kaldes en dannelsesroman, henlagt til et gotisk miljø, hvor heltinden, Emily St. Aubert gennemgår en udvikling fra en følsom til en fornuftspræget person. Radcliffe lægger ud med en beskrivelse af familien St. Auberts harmoniske liv i deres lykkelige dal kaldet La Vallée "on the banks of the Garonne in the province of Gascony in the year 1584."

Emily vokser op i denne "never never world", som regeres med mild hånd af faderen. Trods sin afsondrede tilværelse bliver Emily forberedt til et liv uden for La Vallée og lærer af sin fader at finde en balance mellem klogskab og lidenskab, fornuft og følelse. Men Emilys optagelse i den voksne verden bliver en anden, end faderen havde forestillet sig. Emily bliver revet bort fra sin lykkelige dal, da hendes fader dør. Hun er nu i den for en gotisk heltinde klassiske situation: ubeskyttet, forældreløs med ansvar for sit eget liv. Denne overgang fra den trygge, fornuftsbetonede verden hos forældrene til en usikker verden fuld af trusler og lidenskaber bliver en lige så vigtig del af den gotiske anatomi som slottet og dets overnaturlige hændelser. Emilys kærlige forældre bliver erstattet af tanten, Madame Cheron, en tyrannisk og dominerende kvinde, hvis stærkeste karaktertræk er et ønske om at ydmyge kvinder, der er svagere end hun selv, og af hendes

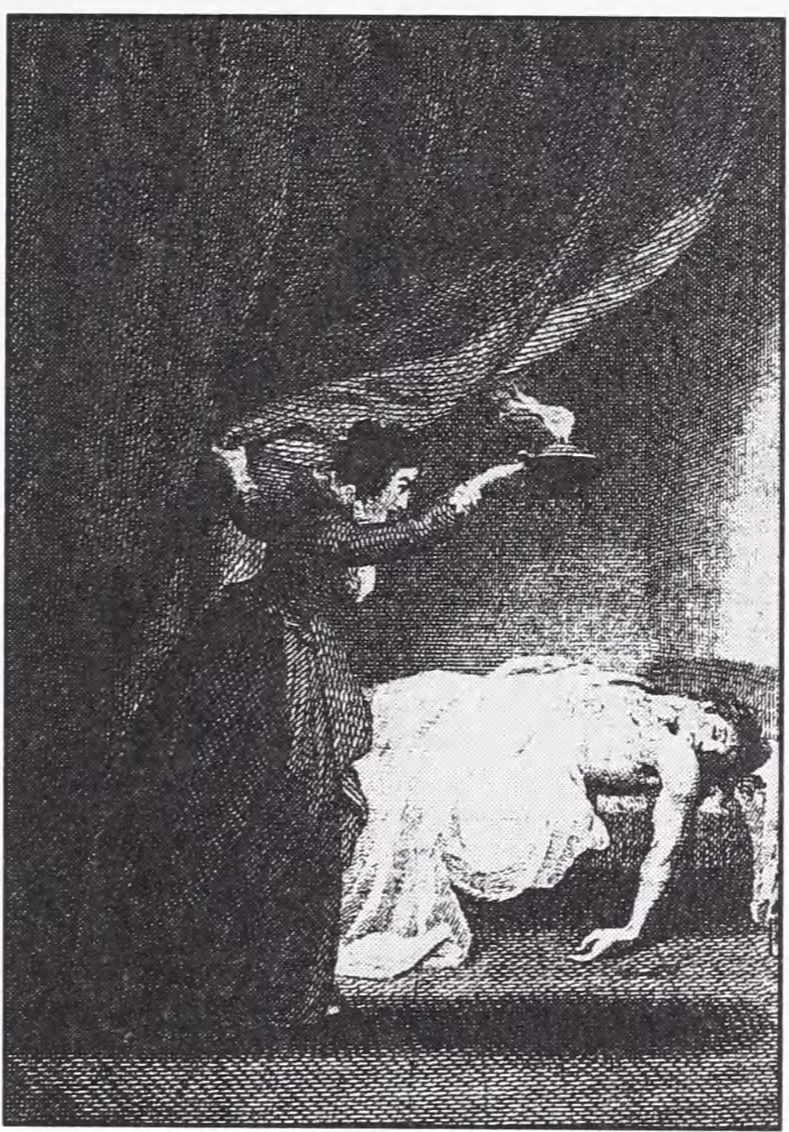

Illustration fra Ann Radcliffe's The Mysteries of Udolpho. Romanens heltinde, Emily, opdager bag et forheng liget af sin myrdede tante.

mand Montoni, den dystre mandsperson, der gennem hele romanen spiller rollen som den strenge fader, der holder de elskende Emily og Valancourt adskilt.

Den idylliske dal erstattes af et truende bjerglandskab: "The gloom of these shades, their solitary silence ... the tremendous precipices of the mountains that came partially to the eye, each assisted to raise the solemnity of Emily's feelings into awe: she saw only images of gloomy grandeur, or of dreadful sublimity, around her." ${ }^{3}$ Bjergene bliver et symbol på det smukke, men frygtindgydende og rædselsvækkende i livet, i fuld overensstemmelse med Edmund Burkes teori: "This landscape, with the 


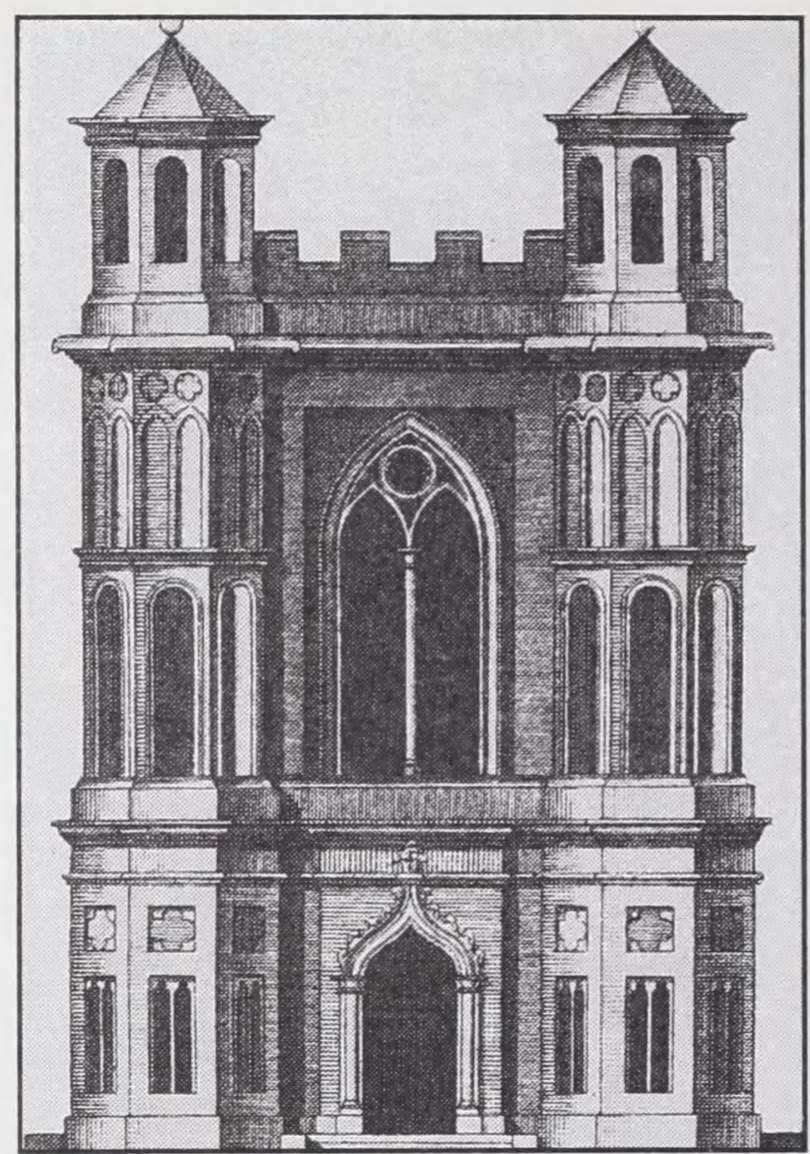

Gotikken var forst og fremmest et litterer bevagelse, men satte sig også spor i arkitekturen. Her ses Batty Langley's forslag til en "Gotisk pavilion", 1742.

surrounding Alps, did indeed present a perfect picture of the lovely and the sublime - 'beauty sleeping in the lap of horror"" 4

Efter et kort ophold i Venedig tager Montoni i følge med Madame Cheron og Emily til sit slot Udolpho, hvor Emily for alvor udsættes for sine prøvelser. Udolpho er den gotiske version af La Vallée. Her hersker alle de farer og fristelser som Emilys gamle verden så ihærdigt forsøgte at holde borte. I sin beskrivelse af Udolpho følger Radcliffe i Walpoles fodspor, men med langt større kunstnerisk overlegenhed:

"Emily gazed with melancholy awe upon the castle, which she under- stood to be Montoni's ... the Gothic greatness of its features, and its mouldering walls of dark grey stone, rendered it a gloomy and sublime object ... Silent, lonely, and sublime, it seemed to stand the sovereign of the scene, and to frown defiance on all who dared to invade its solitary reign." 5

Rundt om hvert hjørne synes noget uhyggeligt og hemmelighedsfuldt at dukke op og forstærke Emilys og læserens nervøse spænding. Vinden, der hyler i de lange gange, brudstykker af samtaler bag lukkede døre, sagte fodtrin og vagten, der ved tusmørkets fald, råber til samling nede på volden, er alle kilder til rædsel og uhygge.

Lige som La Vallée er Udolpho afskåret fra omverdenen, men isolationen har her en anden betydning. Den er et symbol på ejerens totale magt. Montoni er den typiske skurk, der besidder stor intellektuel styrke, som han anvender til forbryderiske formål. Montonis afvisende og mystiske fremtoning og mørke personlighed svarer til det dystre og mørke Udolpho. Den magt, Udolpho har over sine omgivelser, svarer til den kontrol, Montoni har over Emily inden for murene, både fysisk og psykisk. Emily er et passivt offer, der totalt underkastes Montoni: "You speak like a heroine ... we shall see whether you can suffer like one", siger Montoni spottende til den stakkels Emily. ${ }^{6}$

På mange måder ligner Emily enhver anden heltinde fra det 18 . århundrede, på én gang praktisk og følsom. Men hun adskiller sig fra dem på et væsentligt punkt: både de moralske og $ø$ konomiske aspekter af hendes prøvelser 


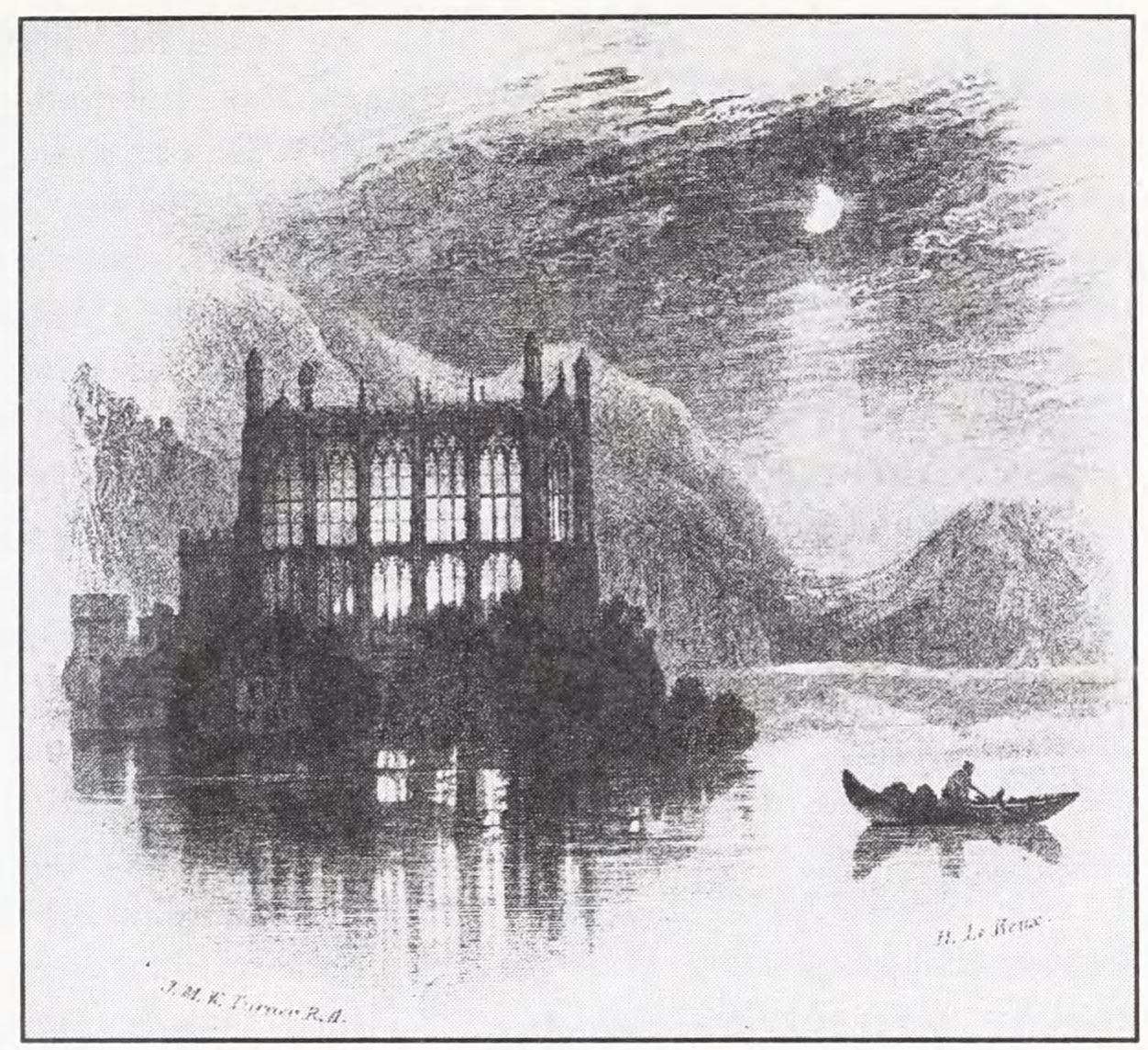

St. Herbert's Chapel. Fra Samuel Roger's Poems, illustreret af William Turner.

er underordnet den kamp, som finder sted i hendes bevidsthed. Hverken Montoni eller de skumle personer, han omgiver sig med, og som truer Emilys dyd, har nær så stor betydning for hende eller læseren som hendes egen frygt. Hvert et fodtrin eller hver en kappeklædt person, der nærmer sig, tror hun enten er et drabeligt tohovedet uhyre eller en af Montonis mænd eller måske er det Valancourt, der er kommet for at redde hende.

Emily er den naturlige videreførelse af de tidligere gotiske heltinder. Men der er sket en stor udvikling i det psykologiske portræt i forhold til Walpoles heltinde Isabella, hvis primære funktion var at løbe skrigende ned gen- nem den mørke tunnel skarpt forfulgt af den onde skurk Manfred. Men Radcliffe tilføjer til de sædvanlige tårer og besvimelser en psykologisk dimension i form af Emilys livlige fantasi.

I dette gotiske univers har Emilys fornuft og selvkontrol svært ved at holde stand, og hun bliver besat af de mange mysterier på Udolpho, som hun føler sig både tiltrukket og frastødt af. Især rygterne om, at den rigtige ejer af Udolpho ikke er Montoni men en vis Signora Laurentini, sætter Emilys fantasi i højeste gear. Hendes tjenestepige Annette fortæller, at i et nærliggende rum hænger et billede af Laurentini bag et sort forhæng. Emilys undersøgelse af dette rum og dets mystiske billede er et 
af højdepunkterne i The Mysteries of Udolpho:

"Emily passed on with faltering steps; and having paused a moment at the door before she attempted to open it, she then hastily entered the chamber, and went towards the picture, which appeared to be enclosed in a frame of uncommon size, that hung in a dark part of the room. She paused again, and then with a timid hand lifted the veil; but instantly let it fall - perceiving that what it had concealed was no picture; and before she could leave the chamber she dropped senseless on the floor..."

Uden at gå i detaljer, men med små antydninger, overlader Radcliffe det meste til læserens og Emilys fantasi. I stedet for $i$ enkeltheder at beskrive det frygtelige, Emily ser bag forhænget, antyder Radcliffe, at hvis det ikke er et billede af Laurentini, må det være damen selv.

\section{Udolphos mysterier kan næ-} sten stå mål med de frygtelige prøvelser, der venter Emily på Chateau Villefort, Emilys sidste gotiske prøvelse efter hendes flugt og det dramatiske skibbrud i nærheden af Chateau Villefort. Hun oplever en frydefuld panik, da hun ser et frygteligt ansigt stirre på sig under et sort tæppe i den seng, der tilhører slottets afdøde frue, the Marchioness de Villeroi. Over flere hundrede sider fastholdes læseren i spændt forventning. Først til allersidst samles trådene, hvor alle de formodet overnaturlige hændelser afsløres som udslag af Emilys livlige fantasi. Det frygtelige ansigt viser sig at tilhøre et medlem af en smuglerbande, der bruger den afdøde Marchioness' stuer som opbevaringsrum for deres gods. Den mystiske sang, der hørtes i skovene omkring Chateau Villefort kommer fra den forstyrrede nonne $\mathrm{Ag}$ nes, der senere afslører sig som den forsvundne Laurentini, den retmæssige ejer af slottet Udolpho! Hvad Emily ser bag det mørke forhæng er kun en meget livagtig voksfigur, opstillet af en tidligere ejer for at minde ham om livets forgængelighed, en bizar udgave af et memento mori.

Emilys gotiske prøvelser bringer hende til fornuft. Intet som hun troede var overnaturligt, viste sig at være det. Montonis slette karakter viser, at det onde ikke er et overnaturligt fænomen men et udslag af menneskets egoisme, som kun kan besejres ved fornuftig selvbeherskelse. Efter at have lært denne lektie vender Emily tilbage til den rationelle verden til La Vallée som voksen kvinde og Valancourts brud.

På en moderne læser virker The Mysteries of Udolpho til tider noget antikveret og komisk. De mange lyriske naturbeskrivelser virker som en hæmsko og har ikke helt den atmosfæreskabende funktion, som var Radcliffes intention. Antydningen af noget overnaturligt har også konsekvenser for handlingsforløbet. Den unaturlige dvælen ved enhver scene forhaler begivenhederne og dermed romanens naturlige slutning: ægteskabet mellem Emily og Valancourt. Men den største indvending, man kunne komme med, er nok Radcliffes brug af "the explained supernatural". Radcliffe lever ikke helt op til den chok-effekt, en moderne læser er forvænt med. En voks- 
figur er ikke tilstrækkelig belønning for læserens trofasthed.

Men når dette er sagt, må man erkende, at Radcliffe på sin egen facon har skabt en spændende og fascinerende historie. Hun behersker sin teknik så mesterligt, at vi villigt lader os føre fra det ene mysterium til det næste. Atmosfæren griber én, og man glemmer at sætte spørgsmålstegn. Hendes beherskelse af antydningens kunst gør også et dybt indtryk. Med The Mysteries of Udolpho har Ann Radcliffe vist vejen for den gotiske genres videre udvikling. Arvtageren bliver en 19 årig ung mand Matthew Lewis, der i 1796 udsender en roman, der chokerer hele den litterære verden: The Monk.

\section{Matthew Lewis og "The Monk"}

$\mathrm{M}$ ed sin blanding af satanisme, overnaturlige hændelser, erotik og sadisme blev The Monk

hurtigt slået fast i publikums bevidsthed som romanen over alle horror-romaner, en roman, der gav Lewis øgenavnet "Monk". The Mysteries of Udolpho var Lewis' inspirationskilde. Men hvor Radcliffe forklarer sine rædsler som udslag af en overophedet fantasi, fremfører Lewis dem som naturlige fænomener. Lewis' kloster har som Udolpho vindeltrapper, grave, fangehuller, hemmelige rum, skjulte gange og gemmer på grufulde hemmeligheder. Hos Radcliffe skabes den uhyggelige stemning, ved hjælp af blafrende stearinlys, kamre hjemsøgt af spøgelser, mens Lewis introducerer Djævelen, magiske spejle og tryllestave i sit gotiske kloster. The Monk rummer også en spøgelseshistorie, "the Bleeding
Nun" ${ }^{\prime \prime}$, som blev myrdet og hvert 5 år går igen i fuld regalia.

The Monk består af to historier vævet ind $\mathrm{i}$ hinanden. Hovedhistorien koncentrerer sig om munken Ambrosio, 33 år, som er abbed for kapucinermunkene i Madrid og tilbedt i hele byen for sin fromhed og godhed. Hans oprindelse er et mysterium. Som spæd bliver han fundet af munkene ved abbediets dør. De tror derfor, han er en gave fra himlen. Med sin ukendte oprindelse er Ambrosio en typisk "would-be hero". Han er en smuk, intelligent og følsom mand, hvis gode egenskaber ødelægges af samfundets hykleri og munkenes opdragelse. Som der står: "The noble frankness of his temper was exchanged for servile humility; and in order to break his natural spirit, the Monks terrified his young mind, by placing before him all the horrors with which Superstition could furnish them..." Munkenes opdragelse er årsagen til, at Ambrosio livet igennem kæmper med et splittet sind.

Gennem hele romanen er Ambrosio i konflikt med samfundet. Han er faktisk samfundets virkeliggørelse af dets egne skjulte modsætninger. Klosterets isolerede verden er blot en endnu mere intens udgave af det omgivende samfund. Livet inden og uden for murene beskrives som et teaterstykke, hvor hykleri og egoisme hersker, hvor alle spiller den rolle, der kræves af dem. Udadtil fremstår klosteret med Ambrosio i spidsen som et billede på dyd, moral og ophøjethed. Indadtil hersker lidenskab og vellyst.

Matilda de Villanegas, Djævelens udsending, får adgang til Ambrosios 


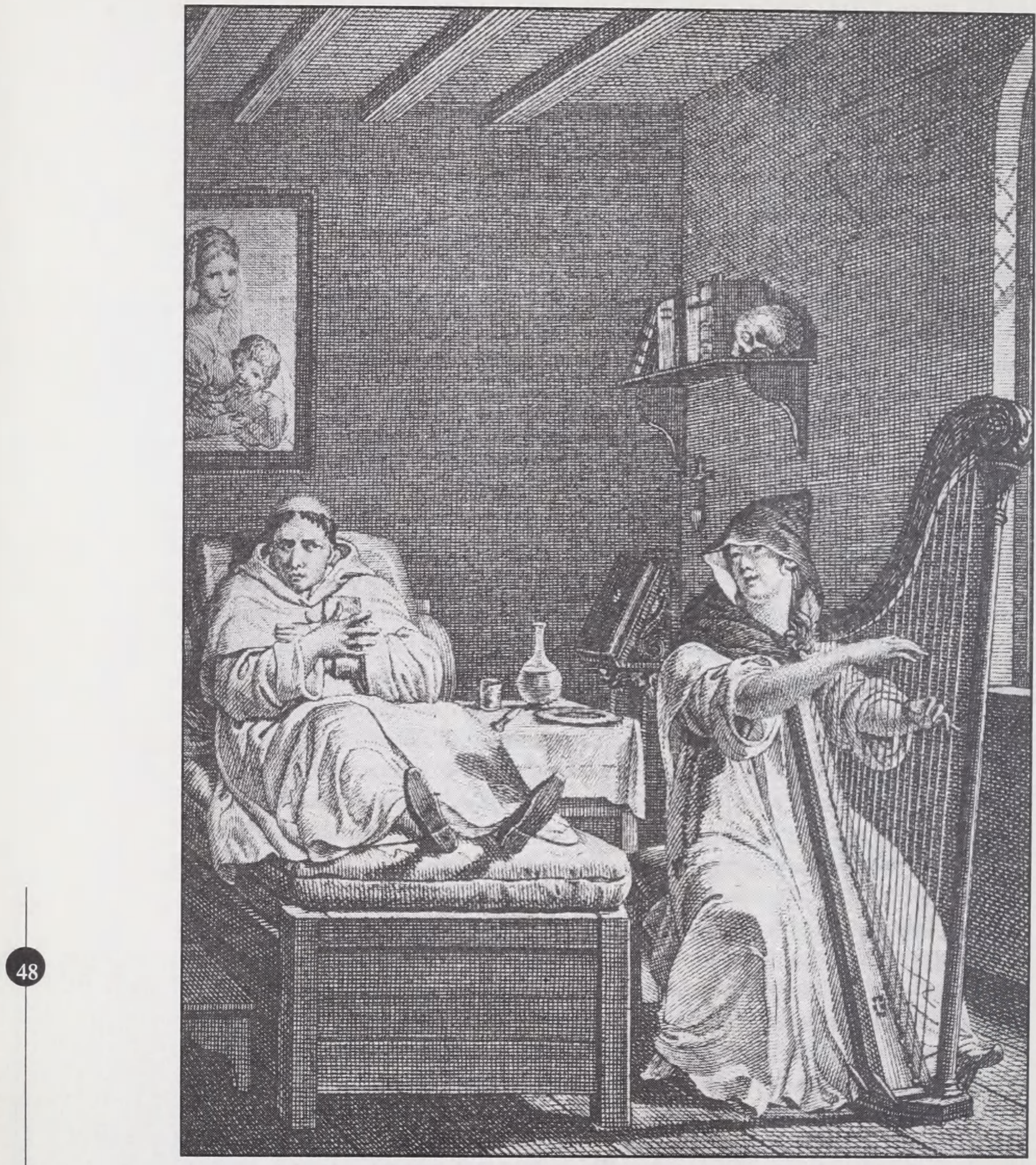

Munken Ambrosio fär besøg af Matilda de Villanegas, Djavelens udsending, forkladt som novicen Rosario. Frontispice fra en fransk udgave af The Monk fra 1807. 
kloster forklædt som novicen Rosario. Hun forfører Ambrosio, og da først hans lidenskab er vakt, kender den ingen grænser. I forholdet til Matilda făr Ambrosio mulighed for at tilfredsstille sine behov samtidig med, at han opretholder den fromme facade. Hans tidligere udtalelser om, at klosterets verden er den perfekte balance mellem isolation og fællesskabets glæder, får således et grotesk udfald: "It secludes Man from the temptations of Vice; It procures that leisure necessary for the proper service of the Supreme; It spares him the mortification of witnessing the crimes of the worldly, and yet permits him to enjoy the blessings of society." ${ }^{10}$ Men Ambrosio bliver hurtigt træt af Matilda og retter sin opmærksomhed mod den uskyldige pige Antonia.

Da Ambrosio ikke i første omgang opnår, hvad han ønsker, må han acceptere Matildas forslag om overnaturlig hjælp, men prisen er høj. Han må sælge sin sjæl. Planen slår fejl, og Ambrosio myrder pigens moder for at forhindre, at hun afslører hans sande karakter. Men med yderligere overnaturlig hjælp lykkes det Ambrosio at bedøve og bortføre Antonia til de dybe hvælvinger under munkeklosteret, hvor hun dybt sovende placeres på en af gravene. En grotesk og frastødende version af Radcliffes "beauty in the lap of horror." Hos Radcliffe føler man en gysen, mens man følger Emily på tåspidserne hen ad en mørk gang, når hun udforsker Udolphos hemmeligheder. I "The Monk" er Lewis rå og direkte $\mathrm{i}$ sine virkemidler, som det fremgår af Ambrosios voldtagelse af Antonia:
"He stifled her cries with kisses, treated her with the rudeness of an unprincipled Barbarian, proceeded from freedom to freedom, and in the violence of his lustful delirium, wounded and bruised her tender limbs. Heedless of tears, cries and entreaties, He gradually made himself Master of her person, and desisted not from his prey, till He had accomplished his crime and the dishounour of Antonia."12

Efter at Ambrosio har forgrebet sig på Antonia, er hun for ham ikke længere det guddommelige væsen, og han vender sig fra hende $i$ afsky.

I en historie parallelt med Ambrosios, fortælles om Don Raymond og hans ulykkelige kærlighed til den gravide nonne Agnes, som er sendt i kloster af sin brutale tante. Da man opdager, hun er gravid, bliver hun af priorinden levende indespærret $i$ et mørkt hul i de dybe hvælvinger under klosteret. I disse omgivelser bringes den gotiske horror roman til et nyt niveau af maksimal væmmelse og afsky hos læseren. Med denne levende begravelse har Lewis benyttet en anden gotisk teknik: klaustrofobisk indespærring, hvor ingen flugt synes mulig, og udsigten til en langsom pinefuld død er sikker. Hos de fleste gotiske forfattere bliver heltinden dog altid reddet i sidste øjeblik uden at have lidt særlig overlast. Men Lewis giver Agnes' indespærring en ganske anden og grusom slutning. Hun føder sit barn alene i dette mørke hul, og beskrivelsen af spædbarnet, der dør af sult i hendes arme har en intensitet, der ikke tidligere er set $\mathrm{i}$ den gotiske genre. Agnes bliver fundet af sin broder Lorenzo, "a Creature 
stretched upon a bed of straw, so wretched, so emaciated, so pale, that $\mathrm{He}$ doubted to think her Woman."13 Lewis tillader Agnes at komme til hægterne, og hun bliver tilsidst gift med Raymond. Men ikke uden at han gentager det samme tema, som er at finde i Ambrosios historie: man må betale en pris for lykken. Agnes må ofre sit barn, Ambrosio sælger sin sjæl til Djævelen i den tro, at han vil opnå et liv i overflod.

Ambrosios død bliver beskrevet $\mathrm{i}$ allersidste kapitel, efter at Raymonds og Agnes' kærlighedshistorie har fået en lykkelig slutning. Lewis forstærker på denne måde indtrykket af Ambrosios ensomhed og fremmedgjorthed. Han kastes i fængsel og forhøres af Inkvisitionen, og herefter følger hans lange udmarvende forhandling med Djævelen om en forlængelse af livet på jorden: Lewis' version af Faust-temaet, om videnskabsmanden, der sælger sin sjæl for at få indblik i den sorte magi. Djævelen bringer ham direkte til de vilde bjerge Sierra Morena i Andalusien, men inden han bliver kastet ned fra klipperne, afsløres hans virkelige identitet. Som en anden Ödipus lærer han først sin familie at kende efter at have ødelagt den. Antonia bliver i sin død en fri sjæl, mens Ambrosio bliver reduceret til et kadaver, ødelagt af den natur, som han forbrød sig mod:

"The Eagles of the rock tore his flesh piecemal, and dug out his eyeballs with their crooked beaks ... Blind, maimed, helpless, and despairing, venting his rage in blasphemy and curses, execrating his existence, yet dreading the arrival of death destined to yield him up to greater torments, six miserable days did the Villain languish. On the Seventh a violent storm arose ... The rain fell in torrents; It swelled the stream; The waves overflowed their banks; They reached the spot where Ambrosio lay, and when they abated carried with them into the river the Corse of the despairing Monk." 14

Ambrosios dødskamp strækker sig over 7 dage, en parallel til skabelsesberetningen. Med sin slutning på romanen viser Lewis, at Ambrosio hele tiden har været offer både for Djævelens og samfundets ondskab. Djævelen, i Matildas skikkelse, har fra begyndelsen haft fuld kontrol over hans liv.

The Monk fik vidtrækkende betydning for den gotisk genres videre udvikling. Da den udkom, vakte den voldsom modstand, og Lewis så sig nødsaget til at revidere romanen flere gange. Den var simpelthen for stærk kost. "The Monk" inspirerede Charles Maturin til romanen Melmoth the Wanderer fra 1820 , som regnes for kulminationen på den gotiske genre. Ligeledes vedstår Hoffmann, at han i sin roman Die Elixiere des Teufels, 1815-16 stod i gæld til Lewis og The Monk. I Danmark fik vi allerede en oversættelse i år 1800 af N.T. Bruun.

Før Ann Radcliffe og Matthew Lewis trådte ind på den litterære scene, skelnede man ikke mellem terror og horror, men The Mysteries of Udolpho og The Monk er eksempler på den store variation og de forskellige indfaldsvinkler til genren, som de gotiske forfattere beherskede. Den forblev ikke statisk, men kan ses som et konstant spil mellem aktion 
og reaktion, en udvikling der først og fremmest er psykologisk: en bevægelse indad, fra ydre beskrivelser af det gotiske slot og naturen, til en beskrivelse af personernes indre kamp mod de mørke kræfter, mennesket bærer på. Hvad

Noter:

1 Burke, Philosophical Enquiry. Oxford University Press: World Classics, 1990, s. 53-54.

2 Citeret efter Frank, The First Gothics, 1987, s. 440.

3 Radcliffe, The Mysteries of Udolpho. London: J.M. Dent \& Sons Ltd., 1949, vol. 1, s. 228. (Everyman's Library; 865)

4 Ibid, bd. 1, s. 56.

5 Ibid, bd. 1, s. 229-30.

6 Ibid, bd. 2, s. 51.

7 Ibid, bd. 1, s. 252.

8 Se Lewis, The Monk, Oxford University Press: World Classics, 1995, især s. 139141.

9 The Monk, s. 237.

10 Ibid, s. 54.

11 Se The Mysteries of Udolpho, bd. 1, s. 56.

12 Ibid, s. 383-384.

13 The Monk, s. 369.

14 Ibid, s. 442.
Radcliffe og Lewis viste med deres fortolkninger af det gotiske univers var, at terror og horror langt fra er to sammenknyttede begreber, men to vidt forskellige bevægelser ganske som Ann Radcliffe selv havde fastslået i sit essay.

Litteraturliste:

Frank, Frederick S.: The First Gothics: A Critical Guide to the English Gothic Novel. New York: Garland Publishing, Inc., 1987. 496 s. Kiely, Robert: The Romantic Novel in England. Cambridge: Harvard University Press, 1973. $275 \mathrm{~s}$.

Kilgour, Maggie: The Rise of the Gothic Novel. London: Routledge, 1995. $280 \mathrm{~s}$.

Lindhard, Annelise: Det "Gothiske" Element $i$ engelsk Kultur i det 18. Aarhundrede. Kbh.: Povl Branners Forlag, 1943. 96 s. (Studier fra Sprog- og Oldtidsforskning; nr. 194)

Punter, David: The Literature of Terror: $A$ History of Gothic Fictions from 1765 to the Present Day. 2. Ed. London: Longman, 1996. 2 Vols.

Varma, Devendra P. : The Gothic Flame Being a History of the Gothic Novel in England: Its Origins, Efflorescence, Disintegration, and Residuary Influences. London: Arthur Barker Ltd., 1957. 264 s. 